3 Dixon N. Medical audit primer. Romsey: Healthcare Quality Quest, 1991: 31-2.

4 World Health Organisation Regional Office for Europe, Copenhagen. The principles of quality assurance. European Reports and Studies 1985; 94: 3.

5 Hall DMB. Health for all children - a programme of child surveillance. Oxford: Oxford University Press, 1992.

6 Health Departments of Great Britain. General practice in the NHS: the 1990 contract: the government's programme for changes to GPs terms of service and remuneration system. London: HMSO, 1990

7 Rigby MJ, McBride A, Shiels C. Computers in medical audit. London: Royal Society of Medicine Services, 1992: 55-7.

8 Osborne D, Lambert P. Child health quality assurance - a practical approach. Adlassnig KP, Grabner G, Bengtsson $S$,
prome practical approach. Adlassnig KP, Grabner G, Bengtsson S,
eds. Proceedings of Medical Informatics Europe 1991. (Vienna, Austria, Aug 1991.) Berlin: Springer Verlag, 1991.

9 Bendell T, Kelly J, Merry T, Sims F. Quality: measurement and monitoring. London: Century Business (Random House), 1993: 48-9.
10 British Paediatric Association. Community child health services: an information base for purchasers. London: BPA, Feb 1992

11 Shaw C. Specialty medical audit. London: Kings Fund Centre, Medical Audit Services, 1992; 4: 13-32.

12 Roethlisberger FJ, Dickson WJ. Management and the worker. Cambridge, Mass: Harvard University Press, 1939: 93-5.

13 Delamothe A. Wanted: guidelines that doctors will follow [Editorial]. BMf 1993; 307: 218.

14 Porter M, Lawler H. Management attitude and performance. Homewood, Illinois: Dorsey Press, 1968: 165.

15 Kelman S. Improving doctor performance - a study in the use of information and organisational change. Center for Policy Research Monograph Series (Etzioni A, series ed). New Research Monograph Series (Etzioni A, series
York: Human Sciences Press, 1980; 1: 28-9.

16 Ovretveit J. Measuring service quality: practical guidelines. TQM Practitioner Series (Zairi M, series ed). New York: Technical Communications (Publishing Ltd), 1993 11-2.

\title{
Tin mesoporphyrin and neonatal jaundice
}

I have referred before (Archivist 1992; 67: 1133) to the potential of haem oxygenase inhibitors for 'turning off the bilirubin tap'. Now a study done on babies in Athens (Timos Valaes and colleagues, Pediatrics 1994; 93: 1-11) has shown that tin mesoporphyrin reduces the postnatal rise in plasma bilirubin.

Normal babies of between 30 and 36 weeks' gestation were given an intramuscular injection of either tin mesoporphyrin $(n=262)$ or saline $(n=202)$ on the first day of life. Mean peak plasma bilirubin concentrations in controls was $198 \mu \mathrm{mol} / \mathrm{l}$. In babies given tin mesoporphyrin mean peak plasma bilirubin fell with increasing dose from $178 \mu \mathrm{mol} / 1$ for those given $2.0 \mu \mathrm{mol} / \mathrm{kg}$ of body weight to $161 \mu \mathrm{mol} / \mathrm{l}$ for those given $6.0 \mu \mathrm{mol} / \mathrm{kg}$. (Both controls and treated babies were given phototherapy when plasma bilirubin reached $214 \mu \mathrm{mol} / \mathrm{l}$.) Phototherapy was given to $62 \%$ of controls, $41 \%$ of those given $2.0 \mu \mathrm{mol} / \mathrm{kg}$ of the drug, and $24 \%$ of those given $6.0 \mu \mathrm{mol} / \mathrm{kg}$. The duration of phototherapy was less in the treated babies.

There was no serious toxicity from the drug. About $10 \%$ of those given the drug plus phototherapy developed a mild erythema on areas of skin exposed to the light. It should be noted that phototherapy was given using 'special blue' lamps and not conventional 'white light' lamps. The emission spectrum of these blue lamps avoids the region of maximum light absorption by tin mesoporphyrin. No other adverse effect of treatment was noted on follow up to the age of 18 months.

It seems, therefore, that tin mesoporphyrin reduces serum bilirubin concentrations in normal preterm newborns. Whether it is preferable to phototherapy or, indeed, whether most of these babies need any treatment at all, may be debated. The authors suggest that it may be useful in developing countries where other means of treating hyperbilirubinaemia may not be available. Whether it is prudent to give to babies a drug of incompletely assessed safety for an essentially benign condition I leave for you to decide. 